a címet pontosan: Сказание о явлениях святому Августину, епископу Ионийскому (Elbeszélés Szent Ágoston, ióniai püspök jelenéseiröl) (vö. L. D. Opulszkaja kommentárjait ld.: Л. Н. Толстой, Собрание сочинений: В 20 т. Москва, ГИХЛ, 1963. Т. 10. С. 565). Ismeretes az orosz filológiában, hogy a három remetéről szóló elbeszélést az író és fordító Andrej Kurbszkij herceg (1528-1583), IV. (Rettenetes) Iván cár hadvezére, majd ellenfele volt, sokfelé hallotta orosz földön, egyebek közt a jeles tudóstól és filozófustól, Makszim Grektől. Makszim Grek tekintélye a Volga menti óhitűek körében később is megőrizte a legendát. Így most ezt az adatot is számon tarthatjuk a Mikes forrásait feltérképező filológiai hálózat egy elemeként, mivel ugyanabból a forrásból ered, mint a nyugatiak, csak az idők folyamán kiegészült más motívumokkal. Legutóbb egy 20. századi orosz költő, Jurij Kuznyecov használta föl költészetében a remetékről szóló vándortörténetet (С. Ю. НиколАеВА, Христианский провидениииализм в поэзии Юрия Кузнецова eprints. tversu.ru/1449/1/Николаева.pdf) - tehát az orosz kultúrában jobban benne maradt a szív imádságának fontosságáról szóló középkori elbeszélés.

S összefoglalásként föltehetjük a kérdést: miért lehet érdekes a Törökországi levelek a külföldi - adott esetben az oroszul olvasó külföldi - számára? Rendelkezik-e a szorosan vett magyar reáliákon kívül olyan sajátosságokkal, amelyek fölkelthetik a nem magyar olvasó, sőt, kutató érdeklődését? A megerősítő válasz magukból a levelekből következik. Az említett tematikai változatosság, a bravúros stílus, a nyelvi és más típusú humor, a korabeli francia levelezés-irodalommal való kapcsolatai és egyéb irodalmi értékei alapján teljes joggal beletartozik a Lityeraturnije pamjatnyiki sorozat gazdag listájába. A fordítónak sikerült olyan „orosz Mikest” teremtenie, amely közeli rokonságban van az eredetivel. Pedig nem volt könnyü feladat Mikes sajátos, a mai magyar nyelvállapothoz képest már kicsit régies, de mégis eleven, sziporkázó stílusát orosz nyelven létrehozni, erőltetett archaizálási kísérletek nélkül. A kötet ezért nemcsak az oroszul olvasó külföldiek számára jelenthet izgalmas újdonságot, hanem magyar közegben (egyetemi szemináriumokon) müfordítás-elemzésekre is kiváló lehetőséget ad, elvi-elméleti kérdések s szorosan vett gyakorlati problémák, a sok találékonyságot és nagy filológiai jártasságot igénylő, minden müfordítónak kihívást jelentő frazeológiai vagy szókincsbeli megoldások számbavételével. Az olvasmányélmény azonban nem a sikeres átültetések mennyiségén múlik, hanem azon, hogy a Leveleskönyv, mint müegész, orosz változatban is rendelkezik egy sajátos, egyéni hangulattal, az író személyiségének átsugárzó erejével.

DukKon ÁGNES

\section{„Volt a hazának egy-két énekem" - Arany 200, Szerk. Boka László, Rózsafalvi Zsuzsanna, Budapest, OSZK, 2018 (Bibliotheca Scientiae et Artis).}

Az Országos Széchényi Könyvtár Bibliotheca Scientiae et Artis sorozatának új kötetéhez kétszeres jubileum kapcsolódik. Tanulmányai ugyanis előadás formában a Nemzeti Könyvtár 2017. évi Tudományos Ülésszakán hangzottak el, amelyet Arany János születésének kétszázadik évfordulójának alkalmából rendeztek. Másfelől maga a gyüjtemény a korábbi ülésszakok anyagát közreadó sorozat első dekádjának záródarabja lett.

A tanulmányok összefoglaló bevezetőjét Rózsafalvi Zsuzsanna írta, aki Boka Lászlóval kötetszerkesztőként is jegyzi a kötetet. Ők ketten, valamint Tóth Zsuzsanna, aki az utolsó tanulmányt/beszámolót írta, az emlékév alkalmát és lehetőségét kihasználva egy virtuális különgyüjteménnyel bővítették az OSZK kézirattári hagyatékokat - ha fizikailag nem is, szellemi értelemben mindenféleképpen. Ugyanis a nagyszalontai Arany-gyüjtemény kéziratainak felmérését, Budapestre szállitását, fizikai helyreállítását, illetve eredeti ôrzési helyükre való visszaszállítását a könyvtár restaurátorai, valamint a tudományos igazgatóság végezte, az utolsó munkafázis 2018. június végén fejeződött be. Mindez a Csonka-torony épületének, kiállítási tereinek, raktárának felújításával egyszerre történt, s a múze- 
umi vonatkozások a Petőfi Irodalmi Múzeum közremúködésével folytak.

Rajnai Edit tanulmánya, amely írás/olvasás, illetve színi előadás/dikció 19. század eleji kérdéseit vizsgálja, Arany János Bolond Istók címü verses regényének néhány, a színpadi beszéddel kapcsolatos, saját tapasztalatait megörökítő sorára keres magyarázatot. A válaszadás azért nehéz, mert az egyszeri színpadi előadás múlékonysága hangrögzítés hiányában - hiába maradtak fenn írásban a hangzásra vonatkozó szabályok, illetve bírálati megjegyzések - nem rekonstruálható. Legfeljebb kéziratok, azok színházi javításai, valamint az előadások kritikai visszhangja alapján lehet bizonyos megállapításokat tenni. Ezek feltárása közben szó esik az előadásra alkalmassá tett szöveg véglegesítésének mühelytitkairól, s amit az magával hozott: előadási hagyomány és újítás kritikusi konfliktusáról.

Szüts-Novák Rita írása Arany János és Tompa Mihály kapcsolatát vizsgálja. Rajtuk kívül azonban a tanulmánynak van egy harmadik szereplője is: az írói levelezés. Az egymástól távol élő, de szellemileg egymásra, a személyiségre, a művekre reflektáló költők kapcsolattartása, amely természetesen harmadik személyekre is kiterjed, magába foglalja a hangulati hullámhegyeket és a hullámvölgyeket, de legföképp megmutatja azt az intellektuális kiszolgáltatottságot, amely értő - nem családi, annál tágabb - olvasóés íróközösség nélküli alkotásra, értő visszhang nélküli munkára ítélheti és ítéli is a saját korába teljesen bele nem simuló alkotót.

Praznovszky Mihály tanulmányában, amely Arany János és Madách Imre kapcsolatával foglalkozik, szintén fontos szerepe van a levelezésnek. Elsősorban ezt a forrást kiaknázva állapítja meg a szerző, hogy nem csak Madáchnak volt szüksége Aranyra, hanem igaz ez fordítva is: a kor másod- vagy harmadrangú átlagában a lapszerkesztő Arany kapva kapott a témájában és nyelvében kiemelkedő, még ha bizonyos átdolgozást is igénylő mü után. De nem csak kapott, hanem befogadását és első visszhangját is befolyásolta, tulajdonképpen ő áll a Madách-recepció elején, annak intézményi és kritikai befogadását is segítve.
Kis Domokos Dániel a nagykőrösi, Arany Jánossal kapcsolatos forrásokat faggatja. Részben a költő-tanárra kíváncsi, részben arra a kollegai/baráti társaságra, amely a református gimnáziumban körülvette; a szerző miniportrékban örökíti meg a személyes kapcsolatokat. Arany tanártársai közül többekkel is közeli, baráti kapcsolatba került, amit elsősorban az értelmiségi lét, illetve a közös kulturális hagyomány/ felfogás erősített. Emellett a visszahúzódó, de vallásos költő jelenlétére számított a Duna melléki református egyházkerület is - közbeszúrt mondattal meg kell említeni, hogy az egyházkerületi jegyzőkönyvek digitalizált változatai a Hungaricana oldalain olvashatók, s a hozzáférés, amely lerövidíti a fáradságos és hosszantartó levéltári munkát, önmagában e vállalkozás hasznát és fontosságát támasztja alá. Arany a nagykőrösi „bizodalmas” kör tagjaival élete későbbi éveiben is találkozott, szellemi kapcsolatukat, egyben a történelmi állandó és változó dialektikus kapcsolatát mutatják azok a mondatok is, amelyeket az aktuálpolitikai érdekü hazafiság irodalmi késztetéséről írt Tompa Mihálynak 1853. május 23-án. Érdemes ezek közül egyet itt is megismételni: „A virágregék épp úgy célra visznek, vagy még jobban, mint a leghazafiasabb költemények".

Izgalmas írás Mikusi Balázsé, bár annak központi alakja nem Arany, hanem a Letészem a lantot címü versét megzenésítő Mosonyi Mihály. A tanulmány szerzője szoros olvasással és „szoros hallgatással” tekinti át a verset, valamint a kottát, az igazi érdekességet azonban a megzenésítés okainak valószínüsítése, az evvel kapcsolatos ismeretek értelmezése jelenti. A német anyanyelvü, családi körülményei miatt autodidakta zeneszerző pályakezdése föleg német zenei mintákra figyelő, ,,kozmopolita” irányultságát az ezernyolcszázötvenes évek végén megváltoztatta, csatlakozott a szükebb közönség által beszélt nemzeti iskolához - csakhogy a befogadás: a közönség, az intézmények és a szakma elismerése nem találkozott várakozásával. Csalódását örökíthette meg Arany verse segítségével, amihez személyes életének tragédiája, feleségének halála is hozzájárulhatott.

Rózsafalvi Zsuzsanna adatgazdag tanulmá- 
nya felfedezés- és értékmentésszámba megy. Ráth Mór 1868-ban kiadott Arany albumát helyezi el a kiadói szándék, Arany János kiadókkal fenntartott kapcsolatai, az illusztrációk készítői, a meghiúsult felújított kiadás, illetve a nagy közönségsikert elért, Zichy Mihály által illusztrált balladás album sarkpontjai között. Tisztán irodalmi tárgyú viszont Szörényi László írása, amely a Toldi szerelme exponált, a szakirodalomban is nehezen értelmezett sorait - föleg az előtte álló első rész fényében - helyezi világirodalmi kontextusba - egyenrangúként idézve Szász Károly, Babits Mihály és Nádasdy Ádám egymást folytató, egyben egymást kikerülő fordításait -, hogy ezáltal adjon magyarázatot azoknak. A tanulmány szerzője azonban nemcsak szövegszerü összefüggéseket nevez meg, hanem keletkezéstörténeti, szerkezeti adalékokra is rámutat, új szempontokkal bővítve az Arany-recepciót.

A kötet legterjedelmesebb, több költő, irodalomtörténész életmúvét mozgató írása Boka Lászlóé, aki Arany János huszadik század eleji befogadását veszi számba, a Nyugat két prominens szerzője, Babits Mihály és Kosztolányi Dezső 1917-es írásai alapján. Tanulmánya azonban sokszorosan túlhalad ezen a célon, mivel bevezetésként áttekinti az 1882 utáni Arany-recepció jellemző vonásait, a differenciálódó irodalmi csoportosulások, felfogások értékrendjét, ezek változását. Babits és Kosztolányi Aranyképének érdekessége, hogy az legalább annyira szolgált elődkeresésre, mint önmaguk reprezentációjára, kapcsolódásra és elhatárolódásra. Babits (tervezett, de meg nem írt) egyetemi szakdolgozatának tárgyául választotta Aranyt, komoly anyaggyüjtő munkával készülve rá, nem beszélve választott elődjét valamilyen módon megidéző verseiről, illetve prózai írásairól. Kosztolányi első megörökített élményei is egyetemista korából valók, 1917-ben pedig több cikkben, ünnepi beszédben említette - mindezt a szerző árnyaltan, gazdag forrásanyagra támaszkodva tárgyalja.

E sorok írója még emlékezik az 1977-es Adyés az 1983-as Babits-centenárium különféle, egymástól egyébként több, megközelítésbeli szempontból különböző kiadványára, többek között az esztergomi-szekszárdi, közös kiadású $F o ̈-$ hajtás Babits Mihály centenáriumán címủ albumra, amely költők, írók, képzőmüvészek Babits által inspirált verseit, emlékezéseit, rajzait tartalmazza. Visy Beatrix, az Országos Széchényi Könyvtár Arany-kiállításának felhívására beküldött versek kötetbe rendezője, hasonló szándékú, de tipográfiailag sokkal szebb válogatást összeállítva, irodalomtudományi szempontokból közelíti meg a jelen Arany-recepcióját, az inspirált, a felidéző, a szövegátvevő és az átíró verseket. A 24 karát címü kötet tematikus áttekintése után Tóth Krisztina és Parti Nagy Lajos egy-egy versét elemzi/értelmezi részletesebben, utóbbi szövegösszefüggéseit táblázatosan is összefoglalva, a két verset függelékben közölve.

Az utókor Arany-képe azonban nemcsak szavakban formálódik meg, legalább ennyire fontos - ahogy az említett Babits-albumban is látható - a képi, grafikai visszatükrözés. Vasné Tóth Kornélia írásában is természetesen Arany János a középpont, de helyt kapnak benne a Petőfi és Tompa inspirálta ex librisek. Az ábrázolások vagy a megjelenést, vagy a müveket adják vissza, a tanulmány a képleírásokat egybefüzi a müvekkel, a levelezéssel, a keletkezés körülményeivel, s gazdag művelődéstörténeti vonatkozásokkal. Jól válogatott illusztrációk támasztják alá mindezt - közéjük némi humort vegyítve Szoboszlai Mata János, aki egyébként Karácsony Sándor bevezetőjével 1941-ben egy Toldi-metszetsorozatot is közreadott - pszeudo ex librisének Don Quijotéra, vagy Merlinre emlékeztető páncélos lovagjával.

Kiváló zenei (és építészeti) párhuzammal indít Deák-Sárosi László Arany János verstani írásainak tárgyalásában. Tanulmányában ütközteti Arany véleményét az utókor felfogásával, megállapítása polemikus-kiegészítő, továbbgondoló jellegú, párbeszédbe lép A magyar nemzeti versidomról címủ írással.

Tárgyában különbözik az eddigiektől a kötetzáró írás, Tóth Zsuzsanna beszámolója. Ebben egy igazi történet bontakozik ki, expozícióval, tetőponttal és megnyugvást hozó befejezéssel - miközben mindezek hátterében ott muzsikál a Trianont követő romániai közgyüjtemények 
idén éppen százéves múltja. Az Arany-év egyik jelentős eredménye volt a nagyszalontai Csonka-torony és a benne található, legnagyobbrészt Arany Jánoshoz kötődő hagyaték állagának felújítása, megjavítása, az épülettől, a kiállítási terekről a raktáron át, a könyvekre és föleg a kéziratokra terjedően. Utóbbiak restaurálása az OSZK mühelyében történt, ahogy már volt erről szó; ez a beszámoló a kötet egyik legérdekfeszítőbb írása lett.

A tavalyi Arany-előadásokat tartalmazó kötet az előzőekhez képest vékonyabb, de tematikailag az egyik legegységesebb, elsősorban irodalom- és kéziratközpontú. Egymás után olvasva a sorozat tagjait, lassan kiteljesedik egyegy munkatárs évtizedre visszatekintő kutatási területe, érdeklődési köre, szakmai hozzáállása, tárgyalásmódja, az előadásokból született tanulmányok erősségei és azok a pontok, amelyek még további kutatást igényelnek. Jól illeszkedik az utóbbi években ehhez a változatos múltú 56-os Intézet jelenléte; az Országos Széchényi Könyvtár BScA-sorozata felnőtté vált.

\section{Buda AtTILA}

\section{Ulrich Andres Wien, Siebenbürgen - Pionier- region der Religionsfreihet. Luther, Honterus und Wirkungen der Reformation, Bonn-Her- mannstadt, Schiller Verlag, 2017. 232 p.}

Az erdélyi reformáció nemzetközi együttmüködésben történő kutatását konferenciák szervezésével és kötetek gondozásával is elősegítő Ulrich Andreas Wien, az Universität Koblenz-Landau keretében müködő Institut für Evangelische Theologie professzora tanulmánykötetében az elmúlt évek termését gyüjtötte össze. Már a címek felsorolása - A vallásszabadság az élenjáró régiónak számitó Erdélyben, $A$ vallási tolerancia alapjai és korlátai a 16. században, A humanista városi reformáció Brassóban és két föszereplöje Johannes Honterus és Valentin Wagner, A reformáció Erdélyben, Helyi vonások a kleinpoldi lelkész Damasus Dürr reformátori prédikációiban, A kálvinizmus hatásai Erdélyben a 16-17. században, Felekezeti térségek kialakulása Erdélyben, A reformátusok tevékenységének visszhangja az erdélyi szász evangélikusok között a 16-17. században, Politika-hatalom-hit, Viták, konfliktusok és egyeztetési törekvések Erdélyben az egyház és a Nationuniversität között a 16. század közepétöl a 18. század derekáig, Az 1572-es Formula Pii Consensus - is jelzi, hogy az erdélyi reformáció kutatói számára megkerülhetetlenül fontos témákról van szó. A felsorolásunkban utolsó elötti helyen szereplö írás itt látja meg először a napvilágot, míg a megjelenés sorrendjében közölt továbbiakat elöször 2000-2016 közötti konferenciakötetekben adta közre. A szerző nem változtatott a szövegeken, csupán egy helyütt találtam (132) a mostani megjelenésre vonatkozó aktualizáló keresztutalást. A változatlan közlés, továbbá az, hogy a tanulmányok zöme olyan németországi konferencián hangzott el, ahol föltétlen szükség volt a történeti háttér és az erdélyi reformáció legfontosabb mozzanatainak ismertetésére, óhatatlanul azzal járt, hogy sok alapvető információ többször szerepel a kötetben. Kétségtelen ugyanakkor, hogy még ezek a történeti bevezetések sem ismétlődnek mechanikusan, mert az egyes tanulmányok fö témájának megfelelően az erdélyi reformáció más-más mozzanatai kerülnek előtérbe.

Másfelől jól tudjuk, mennyire szükséges még a sulykoló ismételgetés is ahhoz, hogy az erdélyi reformáció külön útját és rendhagyó megoldásait megértessük a külföldi szakemberekkel, hiszen sokak erőfeszítése ellenére még az első téma, a sokszor hangoztatott vallási tolerancia esetében sem tekinthető sikeresnek az erdélyi fejlemények kivételességének beláttatása. Nagyon fontos tehát, hogy Ulrich Wien személyében egy, a szász reformációban érdekelt kutató méltatja ezt - a tanulmány címében is tükröződő - elismeréssel. Az augsburgi vallásbéke biztosította toleranciát gyakran túlértékelő német kutatókkal implicit módon vitát folytatva egyenesen arról beszél, hogy Erdély e tekintetben évszázadokkal előzte meg a birodalomban történteket. További erénye a dolgozatnak, hogy világosan feltárja a toleráns gyakorlat kialakulásának folyamatát is. Teljes joggal hangsúlyozza a kötetben több helyen is a folyamatot elindító 1557-es tordai országgyülés kivételes 